\title{
Insurance Industry and China's Regional Economic Development
}

\begin{abstract}
With the development of the financial industry market, China's attention has been drawn to the role of insurance and economic development in the insurance industry. The aim of the paper is to determine the impact and development of the insurance industry of the regional economy; formulate an appropriate policy for the insurance industry. The tasks of the study are to analyze the contribution of the insurance industry to the economic development of China and the impact of property and life insurance on economic growth in the region. The author applies methods such as literature analysis and empirical research. Reference samples selected for the study form a theoretical basis. The paper defines the study model, study variables, and statistics. Based on the research on the economic growth theory, the author uses the endogenous economic growth model to conduct empirical research and test the data of various regions in China from 2013 to 2019. The author uses statistics to conduct empirical analysis and report research findings and interprets empirical results using comparison methods and graphs. The study reveals that life insurance and property insurance are conducive to the steady growth of China's economy, reduce economic risks, promote the development of investment and exports, and promote economic growth. The development of the insurance industry has realized the collection of funds and supported the development of regional industries, and has improved the efficiency of the use of funds. The author concludes that the development of policies of the insurance industry in different regions and the development of the adaptive insurance business are more conducive to economic stability and growth. The findings of the study can be applied to countries with different economic development by region, such as Russia.
\end{abstract}

Keywords: regional economy; the insurance industry; insurance level; property insurance; life insurance; regional differences; the structure of the insurance industry

For citation: Xie X. Insurance industry and China's regional economic development. Finance: Theory and Practice. 2022;26(1):186-197. DOI: 10.26794/2587-5671-2022-26-1-186-197

ОРИГИНАЛЬНАЯ СТАТЬЯ

\section{Страховая индустрия и региональное экономическое развитие Китая}

\begin{abstract}
АННОТАЦИЯ
С развитием рынка финансовой индустрии внимание Китая привлечено к роли страхования и экономического развития страховой отрасли. Цель исследования - определить влияние развития страховой отрасли на рост региональной экономики; сформулировать соответствующую политику для страховой отрасли. Задачи исследования - проанализировать вклад страховой отрасли в экономическое развитие Китая и влияние страхования имущества и жизни на экономический рост в регионах. Использованы методы анализа литературы и эмпирического исследования. Произведен отбор эталонных образцов для формирования теоретической базы, использована модель эндогенного экономического роста для проведения эмпирического исследования и тестирования на данных различных регионов Китая в период с 2013 по 2019 г. Использованы статистические данные для проведения эмпирического анализа и представления результатов исследования. Интерпретированы эмпирические результаты при помощи методов сравнения и графики. Показано, что страхование жизни и имущества способствует устойчивому росту экономики Китая, развитию инвестиций и экспорта, экономическому росту и снижает экономические риски. Страховая отрасль аккумулирует средства и повышает эффек-
\end{abstract}

(c) Xie X., 2022 
тивность их использования, поддерживает развитие региональных отраслей. Сделан вывод, что разработка политики страховой отрасли в различных регионах и развитие адаптивного страхового бизнеса способствуют экономической стабильности и росту. Результаты исследования могут быть применены в странах с различным экономическим развитием регионов, например в России.

Ключевые слова: региональная экономика; страховая отрасль; уровень страхования; страхование имущества; страхование жизни; региональные различия; структура страховой отрасли

Для цитирования: Xie X. Insurance industry and China's regional economic development. Финансы: теория и практика. 2022;26(1):186-197. DOI: 10.26794/2587-5671-2022-26-1-186-197

\section{INTRODUCTION}

The Chinese insurance market has experienced long-term rapid growth since the recovery and has become the most dynamic and highly competitive insurance market in the world with a high degree of marketability. The insurance industry has become a pillar of the financial industry and the national economy and has a huge impact on regional financial stability and economic development [1]. The number of insurance companies has grown from one in 1980 to 239 in $2021 .^{1}$ The changes are shown in Fig. 1.

Among them, there are 12 insurance groups, 1 insurance holding company, 86 property insurance companies, 93 life insurance companies, 14 reinsurance companies, 29 asset management insurance companies, 5 other types of insurance companies, and 119,058 insurance practitioners. Total assets increased from less than 4 billion rubles to $23,298.4$ billion rubles. ${ }^{2}$ The average growth rate exceeded $15 \% .{ }^{3}$ Since 2011 , China's premium income has continued to grow, reaching 452.57 billion rubles in $2020 .{ }^{4}$ Despite the impact of the pandemic, premium income has increased significantly compared to 2019 . The insurance density has increased from 0.47 yuan/person in 1980 to 3460 yuan/person in $2020 .{ }^{5}$ The insurance depth in China's insurance market, from $0.01 \%$ in 1980 to $4.5 \%$ in 2020 [2].

\footnotetext{
${ }^{1}$ National data (2021). National Bureau of Statistics of China. Insurance institutions and practitioners. Insurance Yearbook Data. URL : https://data.stats.gov.cn/easyquery.htm?cn=C 01 (accessed on 03.11.2021).

${ }^{2}$ National data (2021). National Bureau of Statistics of China. Insurance company business economic and technical indicators. Insurance Yearbook Data. URL : https://data.stats. gov.cn/easyquery.htm?cn=C 01(accessed on 03.11.2021).

${ }^{3}$ Iresearch (2021). China Insurance User Demand Trend Insight Report May. 24, 2021. URL: https://www.jiemian.com/ article/6137035.html (accessed on 04.10.2021).

${ }^{4}$ Statistical data (2021). China Banking and Insurance Regulatory Commission. Operation of the insurance industry in 2020. Database. URL : http://www.cbirc.gov.cn/cn/view/ pages/tongjishuju/tongjishuju.html (accessed on 03.11.2021). ${ }^{5}$ School of Finance (2021). Zhongnan University of Finance and Economics. China Insurance Development Report 2021. URL : https://mp.weixin.qq.com (accessed on 03.11.2021).
}

Despite the rapid development of the insurance industry, it is unevenly distributed in the regional economic belt, and the difference in its contribution to economic growth is gradually decreasing [3]. Even within the economic zone, there is a significant imbalance in the development of the insurance industry between the provinces.

\section{LITERATURE REVIEW}

Insurance companies interact with other economic sectors through investment activities to ensure the sound development of the national economy [4]. As a strategic sector, insurance companies have made contributions to sustainable development [5]. Insurance has the functions of economic compensation, financing, and social management [6]. The economic compensation function helps to stimulate consumption and promote technological innovation. The insurance business collects the premium, the capital pool formed and the time difference of compensation make the insurance company obtain a large amount of continuous and stable capital flow.

Insurance companies can use large-scale funds for investment activities to support the development of other economies. The coordination of insurance funds and banking funds is conducive to improving the regional investment system [7].

The social management function in insurance coordinates social and economic life, guarantees social and economic order and increases the efficiency of social operations. This reduces friction between people, enterprises and government and ensures the stability of the social environment for regional economic development within certain limits [8]. Local insurance organizations are one of the main factors in the economic development of developing countries, but the oligopoly also harms the development of the insurance market, which, in turn, affects its economic driving role [9].

Based on the study of time-series data and the model of joint integration, it was found that there is no absolute causal relationship between insurance and economic growth, and significant differences 


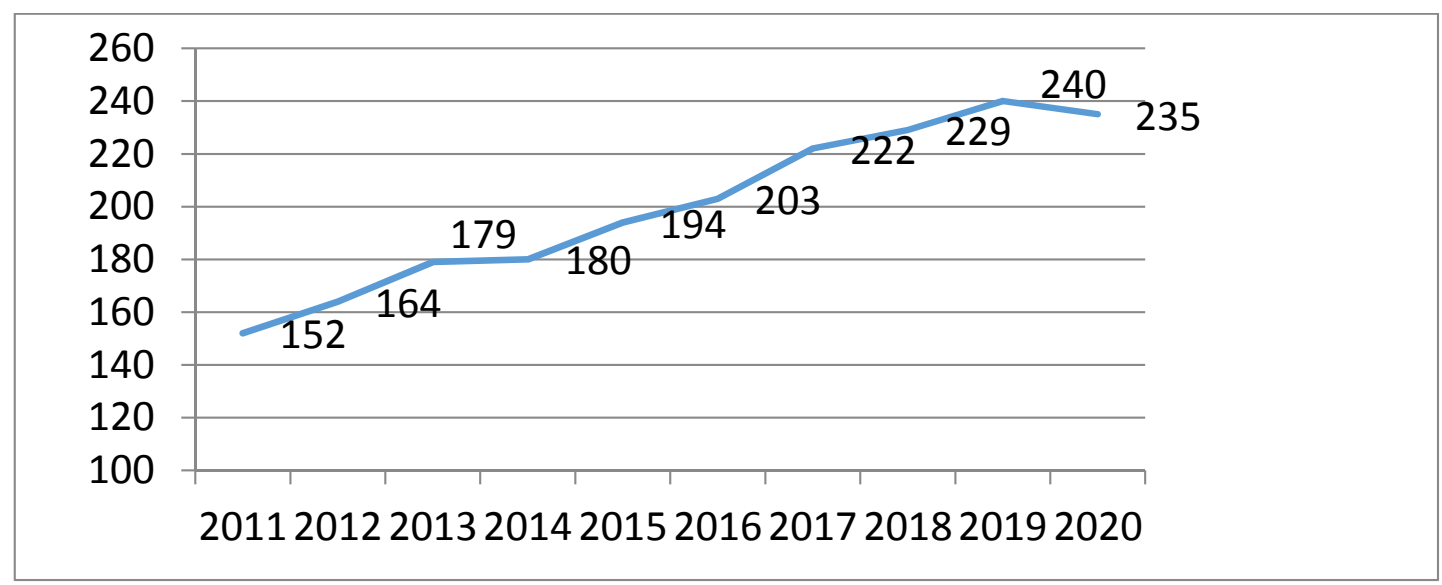

Fig. 1. Number of insurance companies in China's insurance market from 2011 to 2020

Source: compiled by the authors.

between countries are obvious [10]. At the same time, studies based on cross-country data have shown that life insurance contributes to economic growth [11].

Based on the empirical findings of the Solow growth model, the positive impact of the period of interaction between the banking industry and the insurance industry on economic growth is higher than the impact of the banking industry or the depth of insurance [12]. Analyze the impact of the development of the insurance industry on the consumption level of residents. The development of the insurance industry has significantly improved the consumption level of residents and promoted economic growth [13]. The development of insurance markets in both industrialized and developing countries has had a positive and significant causal effect on economic growth [14]. There is a long-term, two-way causal relationship between the life insurance industry and economic growth. The life insurance industry in high-income countries plays a more important role in promoting economic growth [15]. The relationship between the insurance industry and economic growth varies considerably due to the social, cultural, economic, and legal systems of different countries [16]. There is a non-linear relationship between GDP growth and the development of the life insurance industry, and there is an optimal threshold level between them [17].

Different types of grouped countries have different degrees of dependence between indicators of economic growth and the development of indicators of the insurance market, which is determined, not least, by historical, economic, spatial, geographical, and geopolitical characteristics [18]. Empirical analysis of the relationship between the development of the insurance industry and regional economic growth is mainly based on the model of endogenous economic growth. By adding the insurance industry to the endogenous growth model of overlapping generations, analyzing the equilibrium pathway affecting economic growth, it was found that a positive secondary impact of the insurance industry leads to endogenous economic growth [19].

The economic growth mechanism based on the modified Solow-Swan model confirms that insurance affects production activities through investment, which in turn affects economic growth, and the process of promoting economic growth strictly depends on technological progress [20].

The insurance industry has a positive impact on GDP, mainly through risk management, savings substitution and investment promotion. The insurance industry provides business entities with risk transfer and loss compensation services, provides protection against risks and plays a positive external effect, maintaining financial stability, reducing economic fluctuations and hedging economic losses [21]. Shao Quanquan added the development of the insurance industry and the structural variables of property and life insurance into the nonlinear dynamic system model of economic growth and urban-rural income gap, reflecting that the development of life insurance will restrict economic growth and widen the urban-rural income gap. The development of property insurance will promote economic growth and narrow the income gap between urban and rural areas [22]. If the property insurance industry is expanded compared to the life insurance industry, it will narrow the income gap between urban and rural areas and contribute to economic growth.

FORMULATION OF THE PROBLEM The insurance market is characterized by interconnection with other components of the 
country's economy. It has a significant impact on the development of the economy of the country and individual regions. At the same time, the level of economic development and social sphere stimulates the growth and development of the insurance market [23]. Past research has shown that the insurance industry is a guarantee of China's economic growth and stability. With the development of the insurance market, functions such as transfer of insurance risks and compensation, as well as the influence of the structure and functions of the insurance market on regional economic growth, also began to attract more attention [24].

So, what is the internal relationship between the rapid development of the insurance industry, sustainable and stable economic growth in various regions of China, and the gradual improvement in the quality of economic growth? How to play a role in the process of regional economic growth? When formulating economic or financial policies, how should we take into account the sustainable development of the insurance market and limit the volatility of the insurance market?

\section{MODELS, METHODS AND RESULTS}

To explain the impact of the insurance industry on the development of the regional economy, research results in the reference literature modify the Cobb-Douglas function and introduce financial variables into the function to analyze the contribution of the Chinese financial industry to economic growth $[11,12,25]$. Assuming that the financial industry satisfies Hicks' neutral premise of constant return, we created an economic growth model:

$$
Y(t)=Z(t) A(t) K(t)^{\alpha} L(t)^{1-\alpha}, 0<\alpha<1,
$$

Among them, $Y(t)$ is the economic output at $t, A(t)$ technical productivity changes and the exogenous growth rate $g$ is constant, $A(t)=A(0) e g t, K(t)$ - capital at $t, L(t)$ - labor force at $t . Z(t)$ is a financial variable, including banking and insurance.

$$
Z(t)=Z(0) \exp \left(\text { Bank }_{t}+P I_{t}+L I_{t}\right),
$$

In this model, capital and labor are equally diminishing marginal, because

$$
\frac{\partial Y}{\partial L}>0, \frac{\partial Y}{\partial K}>0, \frac{\partial^{2} Y}{\partial^{2} L}<0, \frac{\partial^{2} Y}{\partial^{2} K}<0,
$$

Assuming that technology and labor are fixed constants, take the logarithm of expression (1) and add control variables to get the panel data model:

$$
\begin{gathered}
\ln (G D P)_{i t}=M_{0}+M_{1} P I_{i t}+M_{2} L I_{i t}+ \\
+M_{3} X_{i t}+P_{i t}+\xi_{i t},
\end{gathered}
$$

$G D P_{i t}-G D P$ of province $i$ for period $t$, the only explanatory variable in the model, reflects the regional economy. $P I_{i t}$ and $L I_{i t}$ - are property insurance, life insurance. $X_{i t}$-is the control variable, other variables related to the research include the value of exports, investment in fixed assets, household consumption index, etc., $P_{i t}-$ are other unobservable factors, $\xi_{i t}-$ it is an element of random disturbance.

The model comprehensively considers the control variable $X_{i t}$, which affects economic growth: fixed assets, government spending, total imports and exports, investment in fixed assets, and inflation. These five variables are used to measure actual and human capital investment, trade imports and exports, government intervention, and macroeconomic stability.

To facilitate research, real estate investments are used as fixed capital investments, the financial institution's loan balance at the end of the year is used as bank data, and the CPI is used to measure changes in inflation.

To test the contribution of the development of the regional insurance industry to regional economic growth, we selected 30 provinces in China as the subject of our study according to the division of China's economic regions and re-subdivided the three provinces in the northeast into different economic regions according to their economic level. The data for the period 2013-2019 was selected as a research sample.

As shown in Table 1, the observation patterns are evenly spaced over time. We predict that the development of the insurance market and economic development in different regions are closely related, but the contribution of different types of insurance to GDP growth is different.

We selected 7-year variable data for 30 provinces and regions in China from 2013 to 2019. Then the variable data is logarithmized, and the logarithmic value of the variable is described and analyzed. The results of descriptive data analysis are presented in Table 2.

In order to determine the model used for sample analysis, we tested the data. According to the results of the Hausman test in Table 3, the sample data is 
Panel data structure

Region: $1,2, \ldots, 30$

$n=30, T=7$

Year: 2013, 2014,..., 2019 Delta (year) = 1 unit Span (year) = 7 (region*year uniquely identifies each observation)

\begin{tabular}{|c|c|c|c|c|c|c|c|c|}
\hline \multirow{2}{*}{ Distribution of Ti: } & $\min$ & $5 \%$ & $5 \%$ & $25 \%$ & $50 \%$ & $75 \%$ & $95 \%$ & $\max$ \\
\hline & 7 & 7 & 7 & 7 & 7 & 7 & 7 & 7 \\
\hline Freq. & \multicolumn{2}{|c|}{ Percent } & \multicolumn{2}{|c|}{ Cum. } & \multicolumn{2}{|c|}{ Pattern } & & \\
\hline 30 & \multicolumn{2}{|c|}{100.00} & \multicolumn{2}{|c|}{100.00} & \multicolumn{4}{|c|}{1111111} \\
\hline 30 & \multicolumn{2}{|c|}{100.00} & & & \multicolumn{4}{|c|}{$X X X X X X X$} \\
\hline
\end{tabular}

Source: compiled by the authors.

suitable for the selection of the individual analysis of the fixed-effects model.

\section{EMPIRICAL RESULTS \\ AND EXPLANATIONS}

Using GDP as a variable, property insurance, life insurance, etc. as explanatory variables and using "region" as a cluster variable, stable standard deviation, regression analysis with a fixed effect was performed. From the analysis results in Table 4, it can be seen that a total of 210 samples participated in the regression analysis with fixed effects. In the model Overall $\mathrm{r}$-squared $=0.966, F>P=0.000$, the model is very significant.

In the model group, R-squared within $=0.935$, indicating that the explained change within one is $93.5 \%$. R-squared between $=0.967$, indicating that the Inter-Unit Interpretation Rate is $96.7 \%$.

Overall model $=0.966$, indicating that the overall coefficient of explanatory change is $96.6 \%$. This shows that the model has good explanatory power. During the analysis, SD dependent var $=0.998$, indicating that the variance of the composite disturbance term is mainly due to individual effects rather than changes over time. According to the regression results in Table 4 , we can get the regression model:

$$
\begin{gathered}
g d p=0.152 p i+0.297 l i+0.002 \text { bank }+ \\
+0.303 \text { gov }+0.112 \text { expo }+0.042 \text { fai }-2.83
\end{gathered}
$$

The results of regression analysis show that the coefficients of all independent variables are positive, and the variety of property insurance, personal insurance, import and export, government expenditure, and price index are all significant at the 0.01 level. Fixed asset investment is significant at the 0.05 level.
Table 5 tests the joint significance of the dummy variable coefficients on the basis of regression. The model uses 2013 as the base period to test the data from 2013 to 2019 . It should be noted that year 1 is not included in the construction of the two-way fixed-effects model, because year 1 is regarded as the base period, which is the constant term in the model. Therefore, the 6-year test results are shown in the table. It can be found that all the test values are 0 , and the test accepts the initial hypothesis that there is no time effect, which verifies the conclusion that the model does not need to include the time effect.

The regression coefficients of life insurance and property insurance are positive and have passed the significance test. The empirical results are consistent with the empirical conclusions of scholars such as Rudra P. Pradhan that the growth of the insurance business is conducive to China's risk prevention and thus makes a positive contribution to its economic development [26].

The influence coefficient of the banking industry is positive, but it fails the significance test. This is because China's financial market is a debt-based market and banks' higher funding costs. There is a substitution effect and a competitive relationship between the insurance industry and the banking industry. The development of the insurance industry is more conducive to reducing the cost of capital. The joint development of the insurance industry and banks is more conducive to regional economic growth [27]. For the same reason, China has changed its financial supervision model to meet the needs of economic development. This model, based on specialization and differentiation of regulated objects, seems to be outdated due to the obvious tendency towards universalization of the functions 
Results of descriptive analysis of variables

Table 2

\begin{tabular}{|c|c|c|c|c|c|}
\hline Variable & Obs & Mean & Std. Dev. & Min & Max \\
\hline GDP & 210 & 25412.344 & 21019.223 & 828.2 & 107986.9 \\
\hline $\mathrm{LI}$ & 210 & 271.369 & 203.195 & 7.96 & 1071.14 \\
\hline $\mathrm{PI}$ & 210 & 651.617 & 586.533 & 3.47 & 3041.09 \\
\hline Bank & 210 & 3584.529 & 3495.782 & 27 & 22125 \\
\hline Gov & 210 & 2804.264 & 2332.795 & 95.02 & 12654.53 \\
\hline Expo & 210 & 8821.992 & 15886.019 & 29.266 & 83277.453 \\
\hline Fai & 210 & 3462.51 & 2782.606 & 9.68 & 15852.16 \\
\hline CPI & 210 & 102.955 & 2.449 & 100.6 & 112.2 \\
\hline gdp & 210 & 9.757 & 0.998 & 6.719 & 11.59 \\
\hline li & 210 & 5.273 & 0.928 & 2.074 & 6.976 \\
\hline pi & 210 & 5.973 & 1.235 & 1.244 & 8.02 \\
\hline gov & 210 & 7.58 & 0.944 & 4.554 & 9.446 \\
\hline expo & 210 & 7.859 & 1.741 & 3.376 & 11.33 \\
\hline fai & 210 & 7.735 & 1.114 & 2.27 & 9.671 \\
\hline cpi & 210 & 4.634 & 0.023 & 4.611 & 4.72 \\
\hline
\end{tabular}

Source: China National Bureau of Statistics, China Banking and Insurance Regulatory Commission, wind.

\section{Hausman test result}

\begin{tabular}{|c|c|c|c|c|}
\hline Variable & (b) fe & (B) re & (b - B) Difference & $\begin{array}{c}\text { sqrt (diag }(V b-V B) \\
\text { S. E. }\end{array}$ \\
\hline pi & 0.166 & 0.152 & 0.014 & 0.010 \\
\hline li & 0.280 & 0.297 & -0.017 & 0.016 \\
\hline bank & 0.001 & 0.002 & -0.001 & 0.010 \\
\hline gov & 0.289 & 0.302 & -0.136 & 0.022 \\
\hline expo & 0.110 & 0.112 & -0.003 & 0.012 \\
\hline fai & 0.036 & 0.043 & -0.006 & 0.006 \\
\hline сpi & 1.44 & 1.423 & 0.015 & 0.147 \\
\hline -cons & -2.271 & -2.830 & 0.124 & 0.620 \\
\hline \multicolumn{5}{|c|}{$\begin{array}{l}b=\text { consistent under } \mathrm{Ho} \text { and } \mathrm{Ha} \text {; obtained from xtreg } \\
B=\text { inconsistent under } \mathrm{Ha} \text {, efficient under Ho; obtained from xtreg } \\
\text { Test: Ho: difference in coefficients not systematic }\end{array}$} \\
\hline \multicolumn{5}{|c|}{$\operatorname{chin} 2(8)=(b-B)^{\prime}\left[(V b-V B)^{\wedge}(-1)\right](b-B)=14.72$, Prob $>$ chi2 $=0.0649$} \\
\hline
\end{tabular}

Source: compiled by the authors. 


\section{Regression results}

\begin{tabular}{|c|c|c|c|c|c|c|c|}
\hline gdp & Coef. & St. Err. & t-value & p-value & [95\% Conf & Interval] & Sig \\
\hline pi & 0.152 & 0.043 & 3.53 & 0 & 0.068 & 0.237 & $* * *$ \\
\hline li & 0.297 & 0.077 & 3.84 & 0 & 0.145 & 0.449 & $* * *$ \\
\hline bank & 0.002 & 0.009 & 0.22 & 0.822 & -0.016 & 0.02 & \\
\hline gov & 0.303 & 0.071 & 4.29 & 0 & 0.164 & 0.441 & $* * *$ \\
\hline expo & 0.112 & 0.016 & 7.20 & 0 & 0.082 & 0.143 & $* * *$ \\
\hline fai & 0.042 & 0.023 & 1.87 & 0.062 & -0.002 & 0.087 & $*$ \\
\hline сpi & 1.423 & 0.398 & 3.58 & 0 & 0.644 & 2.202 & $* * *$ \\
\hline Constant & -2.83 & 1.974 & -1.43 & 0.152 & -6.699 & 1.039 & \\
\hline \multicolumn{2}{|c|}{ Mean dependent var } & 9.757 & \multicolumn{3}{|c|}{ SD dependent var } & \multicolumn{2}{|l|}{0.998} \\
\hline \multicolumn{2}{|c|}{ Overall r-squared } & 0.966 & \multicolumn{3}{|c|}{ Number of obs } & \multicolumn{2}{|l|}{210} \\
\hline \multicolumn{2}{|l|}{ Chi-square } & 2977.394 & \multicolumn{3}{|l|}{ Prob > chi2 } & \multicolumn{2}{|l|}{0.000} \\
\hline \multicolumn{2}{|c|}{ R-squared within } & 0.935 & \multicolumn{3}{|c|}{ R-squared between } & \multicolumn{2}{|l|}{0.967} \\
\hline
\end{tabular}

Source: compiled by the authors.

of financial intermediaries, leading to the creation of large financial groups [28]. In 2018, the Chinese government merged the regulatory agencies of the banking and insurance industries, changing from separate supervision to consent supervision. The newly established China Banking and Insurance Regulatory Commission guide the mixed operation of banking and insurance promotes the development of financial conglomerates.

In the 1980s, for economic reform and opening up, during the Seventh Five-Year Plan period, China adopted the economic region division method. According to the differences in the natural conditions, economic resources, economic development level, transportation conditions, and economic benefits of each region, the country was divided into There are three major economic zones in the east, middle and west. From the perspective of economic development level, economic benefit level of production and construction, infrastructure, science, technology, and operation and management, it is generally high in the eastern region, and low in the western region, decreasing from east to west.

According to the level of national economic development, China is divided into three economic zones: eastern, central and western. There are obvious differences between them in terms of geographic location, economic level, distribution

\section{Time effect test results}

\begin{tabular}{|l|l|}
\hline$(1)$ & Year 2 $=0$ \\
\hline$(2)$ & Year 3 $=0$ \\
\hline$(3)$ & Year 4 $=0$ \\
\hline$(4)$ & Year 5 $=0$ \\
\hline$(5)$ & Year 6 $=0$ \\
\hline$(6)$ & Year $7=0$ \\
\hline \multicolumn{2}{|c|}{$F(6,29)=6.48$, prob $>F=0.002$} \\
\hline
\end{tabular}

Source: compiled by the authors.

of population resources and various methods of economic development. There are differences in the contribution of the insurance industry to economic growth in different economic zones. The contribution of property and life insurance to development varies by economic zone. Based on this assumption, we divide the data sample by region and analyze it from a regional point of view. To ensure the continuity of research, the aforementioned measurement models and research methods are still used for data processing. Re-analyze the variable data from 2013 to 2019 according to the division of China's economic zones and subdivide the regions. 
From the above regression results, it can be seen that there are significant differences in the contribution of property insurance and personal insurance to the economic development of various regions. In the eastern and western regions, the contribution of property insurance and personal insurance to economic development is significant, and the regression coefficient in the western region is higher than that in the eastern region from the regression coefficient, which shows that the development of the insurance industry is more conducive to the development of economically backward regions.

From the three tables above, it can be seen that life insurance makes a significant contribution to the economic development of various regions. In China, life insurance has a greater impact in terms of the scale and rate of growth, as well as spillovers and the impact of large-scale development on economic growth. The development of life insurance contributes to the distribution of residents' incomes between consumption and savings, increases the marginal propensity of residents to consume and helps to stimulate domestic demand. At the same time, it promotes the allocation of savings among various investments, realizes the efficient allocation of capital and provides low-cost capital support for economic growth, and also expands the scale of cost-effective capital.

In Table 7, the correlation coefficient of property insurance in the central region did not pass the significance test, indicating that the development of property insurance in the central region did not contribute significantly to economic growth. This is because the economic growth of central China, mainly relies on the development of secondary industries and infrastructure investment, and government bonds and bank provisions are the main providers of economic development funds. Although property insurance premiums have increased rapidly, the use of funds is insufficient and investment channels are insufficient. The impact of property insurance on economic growth through economic compensation is negligible, and the financing function of the insurance industry does not really play a role.

In the eastern and western regions, banks' regression coefficients did not pass the significance test, indicating that the insurance industry is making a relatively high contribution to economic growth here. It also shows the competition and the substitution relationship between the insurance industry and the banking industry. Currently, most banks are also actively expanding their insurance activities for reasons of profit and scale. today practically all types of insurance are sold through bank sales channels. Despite the fact that property insurance, protection against financial risks, accidents and life insurance are most successfully sold in addition to retail loans, a significant share in the package of bank insurance sales belongs to non-credit insurance. Bank insurance will gradually replace the unified banking business model. This relationship is more evident in economically developed regions.

\section{OUESTIONS DISCUSSIONS}

The contribution of insurance to economic growth varies with the degree of regional economic development. The developers of the digital economy and the popularization of mobile terminal equipment have overturned the traditional development model of the insurance industry. Advances in insurance technology have enabled insurance companies to provide insurance services and products for individuals, breaking through the limitations of regional space [29]. Insurance will be able to better adapt to the development needs of various economic regions and enter a wider range of fields. The research on the contribution of the insurance industry to regional development needs to consider the impact of the digital transformation of the insurance industry. This is also the direction of continued research in the future.

\section{CONCLUSION}

Through data model analysis, Table 4 proves that the development of the insurance industry is conducive to the growth of China's regional economy. The regression coefficients of property insurance and life insurance are 0.166 and 0.28 , respectively, which have a significant role in promoting China's regional economic growth. From a national perspective, life insurance has a greater contribution to economic growth than property insurance [24]. However, in different economic zones, the development of property insurance has significant differences between regions. Tables 6 and Tables 8 confirm the contribution of property insurance to economic growth. In the economically developed eastern region $(0.191)$ and the economically backward western region. The region $(0.195)$ is more prominent, significantly higher than the central region (0.038).

In China's three economic zones, life insurance has a positive effect on economic growth. Comparing the empirical results, the regression coefficients of 


\section{Regression results in the eastern region}

Table 6

\begin{tabular}{|c|c|c|c|c|c|c|c|}
\hline gdp & Coef. & St. Err. & $t$-value & $p$-value & [95\% Conf & Interval] & Sig \\
\hline pi & 0.191 & 0.058 & 3.32 & 0.002 & 0.076 & 0.307 & $* * *$ \\
\hline li & 0.229 & 0.116 & 1.97 & 0.054 & -0.004 & 0.463 & * \\
\hline bank & 0.015 & 0.02 & 0.76 & 0.448 & -0.025 & 0.055 & \\
\hline gov & 0.33 & 0.1 & 3.30 & 0.002 & 0.129 & 0.531 & $* * *$ \\
\hline expo & 0.19 & 0.09 & 2.10 & 0.04 & 0.009 & 0.371 & $* *$ \\
\hline fai & -0.034 & 0.052 & -0.65 & 0.516 & -0.138 & 0.07 & \\
\hline cpi & -0.237 & 1.344 & -0.18 & 0.86 & -2.934 & 2.459 & \\
\hline Constant & 4.484 & 6.047 & 0.74 & 0.462 & -7.645 & 16.614 & \\
\hline \multicolumn{2}{|c|}{ Mean dependent var } & 10.373 & \multicolumn{3}{|c|}{ SD dependent var } & \multicolumn{2}{|c|}{0.838} \\
\hline \multicolumn{2}{|c|}{ R-squared } & 0.910 & \multicolumn{3}{|c|}{ Number of obs } & \multicolumn{2}{|c|}{70} \\
\hline \multicolumn{2}{|c|}{ F-test } & 76.885 & \multicolumn{3}{|c|}{ Prob $>\mathrm{F}$} & \multicolumn{2}{|c|}{0.000} \\
\hline \multicolumn{2}{|c|}{ Akaike crit. (AIC) } & -205.251 & \multicolumn{3}{|c|}{ Bayesian crit. (BIC) } & \multicolumn{2}{|c|}{-187.263} \\
\hline
\end{tabular}

Source: compiled by the authors.

\section{Regression results of the central region}

Table 7

\begin{tabular}{|c|c|c|c|c|c|c|c|}
\hline gdp & Coef. & St. Err. & $t$-value & $p$-value & [95\% Conf & Interval] & Sig \\
\hline pi & 0.038 & 0.059 & 0.65 & 0.517 & -0.08 & 0.157 & \\
\hline li & 0.305 & 0.1 & 3.04 & 0.004 & 0.103 & 0.508 & $* * *$ \\
\hline bank & 0.027 & 0.013 & 2.07 & 0.045 & 0.001 & 0.053 & $* *$ \\
\hline gov & 0.366 & 0.077 & 4.77 & 0 & 0.211 & 0.521 & *** \\
\hline expo & 0.097 & 0.041 & 2.40 & 0.021 & 0.015 & 0.179 & $* *$ \\
\hline fai & 0.04 & 0.039 & 1.04 & 0.306 & -0.038 & 0.118 & \\
\hline сpi & 2.774 & 0.86 & 3.23 & 0.002 & 1.038 & 4.511 & *** \\
\hline Constant & -8.839 & 4.004 & -2.21 & 0.033 & -16.926 & -0.752 & ** \\
\hline \multicolumn{2}{|c|}{ Mean dependent var } & 9.952 & \multicolumn{3}{|c|}{ SD dependent var } & \multicolumn{2}{|c|}{0.513} \\
\hline \multicolumn{2}{|c|}{ R-squared } & 0.973 & \multicolumn{3}{|c|}{ Number of obs } & \multicolumn{2}{|c|}{56} \\
\hline \multicolumn{2}{|c|}{ F-test } & 214.815 & \multicolumn{3}{|c|}{ Prob $>F$} & \multicolumn{2}{|c|}{0.000} \\
\hline \multicolumn{2}{|c|}{ Akaike crit. (AIC) } & -234.070 & \multicolumn{3}{|c|}{ Bayesian crit. (BIC) } & \multicolumn{2}{|c|}{-217.867} \\
\hline
\end{tabular}

Source: compiled by the authors. 
Regression results in the western region

\begin{tabular}{|c|c|c|c|c|c|c|c|}
\hline gdp & Coef. & St. Err. & $t$-value & $p$-value & [95\% Conf & Interval] & Sig \\
\hline pi & 0.195 & 0.04 & 4.85 & 0 & 0.115 & 0.275 & $* * *$ \\
\hline li & 0.402 & 0.075 & 5.36 & 0 & 0.252 & 0.552 & $* * *$ \\
\hline bank & -0.006 & 0.008 & -0.82 & 0.417 & -0.021 & 0.009 & \\
\hline gov & 0.086 & 0.084 & 1.03 & 0.307 & -0.081 & 0.254 & \\
\hline expo & 0.098 & 0.017 & 5.84 & 0 & 0.064 & 0.131 & $* * *$ \\
\hline fai & 0.057 & 0.022 & 2.59 & 0.012 & 0.013 & 0.1 & ** \\
\hline cpi & 2.256 & 0.475 & 4.75 & 0 & 1.308 & 3.203 & $* * *$ \\
\hline Constant & -5.87 & 2.316 & -2.54 & 0.014 & -10.495 & -1.246 & $* *$ \\
\hline \multicolumn{2}{|c|}{ Mean dependent var } & 9.115 & \multicolumn{3}{|c|}{ SD dependent var } & \multicolumn{2}{|c|}{0.994} \\
\hline \multicolumn{2}{|c|}{ R-squared } & 0.970 & \multicolumn{3}{|c|}{ Number of obs } & \multicolumn{2}{|c|}{84} \\
\hline \multicolumn{2}{|c|}{ F-test } & 298.646 & \multicolumn{3}{|c|}{ Prob $>F$} & \multicolumn{2}{|c|}{0.000} \\
\hline \multicolumn{2}{|c|}{ Akaike crit. (AIC) } & -320.246 & \multicolumn{3}{|c|}{ Bayesian crit. (BIC) } & \multicolumn{2}{|c|}{-300.800} \\
\hline
\end{tabular}

Source: compiled by the authors.

life insurance in the three major economic zones in the east, middle and west are: 0.229, 0.305, 0.402 . Obviously, the contribution of life insurance to regional economic growth increases from the east to the west. The development of life insurance is more conducive to the economic development of economically underdeveloped regions.

It should be noted that the imbalance in the regional economic development of China has led to an imbalance in the insurance market, and there are significant differences in the level of development and development structure of the insurance industry. The contribution of the development of the insurance industry to the economic growth of the region depends on the structure of the development of the insurance industry. ${ }^{6}$ In various regions, it is necessary to develop targeted regulatory policies based on the characteristics of regions' economic growth so that the insurance function can be fully

\footnotetext{
${ }^{6}$ Prospective Research Institute. Analysis of the development status and industrial structure of China's insurance industry in 2021. 13. 03.021. URL: https://www.qianzhan.com/analyst (accessed on 04.10.2021).
}

utilized and ensure sustainable growth of the regional economy.

Thus, changes in regional economic policy and the economic environment will affect the development of the insurance industry. In the process of development, insurance companies need to consider whether property insurance products can adapt to the characteristics of regional economic development in order to adjust their development [30]. As a strategy, you can use the insurance function so that the regional economy of the country grows constantly.

Whether the additional effects and substitution effects of the banking and insurance industries have an impact on the development of the regional economy, and how the insurance industry can play a more significant role in the process of regional economic growth, cannot be expressed in the model and needs to be investigated further. The structure of the insurance industry affects economic growth in different ways [31]. There are differences in the functions of economic management, risk compensation and social management in insurance at different levels of economic zones, and differentiated insurance policies need to be developed. 


\section{REFERENCES}

1. Hu Hongbing. 2021 China insurance development report. Wuhan: School of Finance, Zhongnan University of Finance and Economics, China. 04.20.2021. URL: https://mp.weixin.qq.com (In Chinese).

2. Ren Zeping. 2021 China insurance industry development report: From rapid expansion to high-quality development. 17.03.2021. URL: http://finance.sina.com.cn (In Chinese).

3. Xiao Pan. The impact of non-equilibrium development of insurance on the quality of economic growth in China. Changsha: Hunan University; 2016. 23 p. (In Chinese).

4. Chi-Chuan Lee, Chien-Chiang Lee. Insurance activity, real output, and geopolitical risk: Fresh evidence from BRICS. Economic Modelling. 2020;92:207-215. DOI: 10.1016/j.econmod.2020.01.001

5. Belozerov S.A., Kuznetsova N.P., eds. Insurance and risk management: Problems and perspectives. Moscow: Prospekt; 2017. 528 p. (In Russ.).

6. Azman-Saini W.N.W., Smith P. Finance and growth: New evidence on the role of insurance. South African Journal of Economics. 2011;79(2):111-127. DOI: 10.1111/j.1813-6982.2011.01258.x

7. Wu Yonggang, Li Zheng. The effect of insurance development on economic growth in China: Based on the view of financial synergy. Nankai Economic Studies. 2013;(4):82-94. DOI: 10.14116/j.nkes.2013.04.003

8. Li Keqiang. 2021 government work report. China People’s Daily. 07.03.2021. URL: https://www.nia.gov.cn (In Chinese).

9. Outreville J.F. Life insurance markets in developing countries. The Journal of Risk and Insurance. 1996;63(2):263-278. DOI: $10.2307 / 253745$

10. Ward D., Zurbruegg R. Does insurance promote economic growth? Evidence from OECD countries. The Journal of Risk and Insurance. 2000;67(4):489-506. DOI: 10.2307/253847

11. Cha Qifen, Zhang Zhi. Research on the contribution of insurance development to regional economic growth - take Jiangsu Province as an example. Accounting and Finance. 2017;166(2):1-5. (In Chinese).

12. Webb I.P., Grace M.F., Skipper H.D. The effect of banking and insurance on the growth of capital and output. Center for Risk Management and Insurance Working Paper. 2002;(02-1). URL: http://citeseerx.ist.psu.edu/ viewdoc/download?doi=10.1.1.535.3081\&rep=rep1 \& type=pdf

13. Beck T., Webb I. Economic, demographic and institutional determinants of life insurance consumption across countries. The World Bank Economic Review. 2003;17(1):51-88. URL: https:// openknowledge.worldbank.org/bitstream/handle/10986/17169/773990JRN020030ts0of0Life0Insurance. pdf? sequence $=1$ \&isAllowed $=\mathrm{y}$

14. Arena M. Does insurance market activity promote economic growth? A cross-country study for industrialized and developing countries. The Journal of Risk and Insurance. 2008;75(4):921-946. URL: https:// openknowledge.worldbank.org/bitstream/handle/10986/9257/wps4098.pdf?sequence=1 \&isAllowed=y

15. Lee C.-C. Does insurance matter for growth: Empirical evidence from OECD countries. The B. E. Journal of Macroeconomics. 2011;11(1):1-28. DOI: 10.2202/1935-1690.2080

16. Burcă A.M., Armeanu D., Kagitci M. An empirical analysis of the causality relationship between insurance and economic growth. In: Proc. Int. conf. "Finance and Banking - FIBA 2013" (Bucharest, Mar. 28-29, 2013). Bucharest: Bucharest University of Economic Studies; 2013:17-29.

17. Yang S.-Y., Li H.-A., Fang H.-C. The non-linear relationship between economic and life insurance development in Asia: A panel threshold regression analysis. In: Computer Science and its Applications: Ubiquitous Information Technologies. Berlin, Heidelberg: Springer-Verlag; 2015:1281-1290. (Lecture Notes in Electrical Engineering). DOI: 10.1007/978-3-662-45402-2_179

18. Prokopjeva E., Kuznetsova N., Kalayda S. Insurance market development and economic growth indicators: The study of relationship in the world. Ekonomichnii chasopis-XXI = Economic Annals-XXI. 2020;185(910):48-60. DOI: 10.21003/ea.V185-05

19. Corneo G., Marquardt M. Public pensions, unemployment insurance, and growth. Journal of Public Economics. 2000;75(2):293-311. DOI: 10.1016/S0047-2727(99)0058-4

20. Yuan Cheng, Yu Run. The contribution of insurance development to economic growth based on the theory of multiple functions Dedicated empirical test. Financial Essays. 2013;(1):40-46. (In Chinese). DOI: 10.13762/j.cnki.cjlc.2013.01.006

21. Haiss P., Sümegi K. The relationship between insurance and economic growth in europe: A theoretical and empirical analysis. Empirica. 2008;35(4):405-431. DOI: 10.1007/s10663-008-9075-2 
22. Shao Quanquan. The impacts of insurance industry on the nonlinear dynamic system of "Economic growth - rural and urban income gap”. Modern Economic Science. 2015;(2):37-47. (In Chinese).

23. Zheng Hui, Wang Tao. Research on the dynamic relationship between insurance development and economic growth in coastal areas based on local polynomial model. Journal of Central University of Finance and Economics. 2015;(10):86-93. URL: https://6699/kns/defaultresult/index (In Chinese).

24. Bairoliya N., Miller R. Social insurance, demographics, and rural-urban migration in China. Regional Science and Urban Economics. 2021;91:103615. DOI: 10.1016/j.regsciurbeco.2020.103615

25. Zeng Qian, Xuyang. The different economic growth effect from our country insurance market in financial deepening-based on time-varying panel smooth transitional regression model. Industrial EconomicReview. 2017;(4):93-109. (In Chinese). DOI: 10.14007/j.ckin.cjpl.201704.009

26. Pradhan R.P., Avrin M.B., Nair M., Hall J.H., Gupta A. Is there a link between economic growth and insurance and banking sector activities in the G-20 countries? Review of Financial Economics. 2017;(33):1228. DOI: 10.1016/j.rfe.2017.02.002

27. Balcilar M., Gupta R., Lee C.-C., Olasehinde-Williams G. The synergistic effect of insurance and banking sector activities on economic growth in Africa. Economic Systems. 2018;42(4):637-648. DOI: 10.1016/j. ecosys.2018.08.002

28. Belozerov S.A. InsurTech as a factor in the development of the insurance industry. In: Insurance in the information society: Place, tasks, prospects. Proc. $20^{\text {th }}$ Int. sci.-pract. conf. (Vladimir, June 4-6, 2019). Vladimir: Vladimir State University; 2019:45-50. (In Russ.).

29. Liao $\mathrm{Pu}$. The positive role of property insurance towards long term economic growth - from the risk transfer and compensation function perspective. Insurance Studies. 2017;(6):32-46. (In Chinese). DOI: 10.13497/j.cnki.is.2015.06.004

30. Zhao Wenjin, Xing Tiancai, Xiong Lei. The effect of insurance consumption on economic growth in China. Economic Research. 2010;(2):39-50. (In Chinese).

31. Zeng Zhi, Yao Peng, Yang Guang. Analysis of insurance market's nonlinear effect on economic growth in China. Insurance Studies. 2014;(12):17-23. (In Chinese). URL: 10.13497/j.cnki.is.2014.12.002

\section{ABOUT THE AUTHOR / ИНФОРМАЦИЯ ОБ АВТОРЕ}

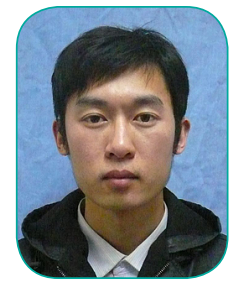

Xiaohe Xie - Post-Graduate Student, Department of Risk Management and Insurance, Faculty of Economics, St. Petersburg State University, St. Petersburg, Russia

Cяохе $\boldsymbol{C e}$ - аспирант кафедры управления рисками и страхования, экономический факультет, Санкт-Петербургский государственный университет, Санкт-Петербург, Россия https://orcid.org/0000-0001-9845-9044

xxh1467@yandex.ru

Конфликт интересов: автор заявляет об отсутствии конфликта интересов.

Conflicts of Interest Statement: The author has no conflicts of interest to declare.

The article was submitted on 15.07.2021; revised on 31.07.2021 and accepted for publication on 17.12.2021.

The author read and approved the final version of the manuscript.

Статья поступила в редакцию 15.07.2021; после рецензирования 31.07.2021; принята к публикации 17.12.2021. Автор прочитал и одобрил окончательный вариант рукописи. 